\title{
The Linkage of Entrepreneurial Motivation on Marketing Performance SME's in Covid-19
}

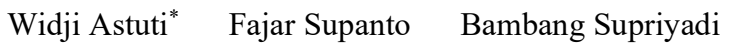 \\ University Of Merdeka Malang
}

\begin{abstract}
The present study aims to investigate the linkage of entrepreneurial motivation on marketing performance SME at the Covid-19 Pandemic. The study has been conducted through descriptive quantitative method. The questionnaire of the study developed to investigate entrepreneurial motivation and marketing performance, this survey to 169 entrepreneurs food and beverage have been selected as the sample. Data analysis was carried out using the statistical program package PLS version 19. The results of the study indicate that there is a direct and positive significant relationship between entrepreneurial motivation and marketing performance. Of the dimensions of entreprenerial motivation, self efficacy, creativity and innovation, need achievement, and future oriented is able to produce marketing performance. Conclusions of this research is mindset and strategic thinking positive can tolerate business problems and market share are increased.
\end{abstract}

Keywords: Entrepreneurial Motivation, Marketing Performance

DOI: $10.7176 / \mathrm{JESD} / 12-22-08$

Publication date: November $30^{\text {th }} 2021$

\section{Introduction}

Today, the organization's activities in a very dynamic environment, it is important and significant to attention to human resources as one of the effective capital for the company. In the past, scarce resources, technological advantages, patents and state regulations were competitive advantages. However, technological development, rapid innovation and the abolition of regulations led to the removal of boundaries. In the current environment requires flexibility, innovation and speed in market, development and management of knowledge, experiences, skills, and specialization (as called human capital) as a key factor for the effectiveness and sustainable business of successful marketing performance.

In an effort to determine the growth factors of SMEs, several studies have focused on entrepreneurs and the environment. Another study looked at entrepreneurs, company and corporate strategy. But Baum, Locke, \& Smith (2001) found different results, that entrepreneurial motivation (EM) has a direct impact on business growth while environment has an indirect effect. Motivation is generated from self-efficacy, growth goals and vision with other factors such as general and specific competencies chief executive officer and competitive strategy. In a follow-up study, Baum \& Locke (2004) examined entrepreneurial motivation (consisting of goals, efficacy, and vision) found that all three had a direct effect on business growth. Business growth can occur due to three interrelated components: entrepreneurs, companies and strategy. These three things become the basis for entrepreneurs to make decisions, and choose the right strategy so that marketing performance runs to achieve its goals. The success of marketing performance can be measured by sales growth, profitability and market share growth (Nuryakin et al, 2016; Kirca et al, 2005).

This paper will focus on entrepreneurial motivation, arguing that EM is generally under-investigated in the entrepreneurship literature, especially on its contribution to marketing performance. In addition, previous theories and research often treat entrepreneurial motivation as if it already existed when someone became an entrepreneur. In fact, in the journey of entrepreneurship, this motivation plays an important role. However, EM is a different concept with a unique relationship to generate marketing performance as the spearhead of a business. Thus, this research problem is more interesting in some basic aspects because some of the assumptions that have been made so far have shifted. This paper has the following research objectives: To develop a comprehensive but concise model of the linkage of entrepreneurial motivation to marketing performance.

\section{Literature Review}

Entrepreneurship has become the main issue that is the focus of local government and community agreements (Avgerou and $\mathrm{Li}, 2013$ ). At the same time, entrepreneurship can further enhance social stability and promote sustainable and rapid economic development. It is necessary to strengthen and analyze entrepreneurship motivation in an objective and practical manner.

Entrepreneurial motivation is a process that activates and encourages entrepreneurs to exert higher efforts to achieve their entrepreneurial goals. Business continuity is the most important form of entrepreneurial motivation. Many researchers have noted aspects of entrepreneurial motivation, analyzing how various factors influence entrepreneurial motivation. Gerry et al. (2005) introduces new constructs and uniquely incorporates in defining entrepreneurial motivation i.e. the perceived net desire of entrepreneurs (NDSE), perceived self-efficacy (SE), and 
tolerance for risk (TR). Su et al. (2020) explores the interaction between positive emotions and entrepreneurial motivation. The results showed that positive emotions significantly affect on entrepreneurship motivation and the entrepreneurial process of entrepreneurs. Barta et al. (2019) examines entrepreneurial motivation and result that the social mission factor is the main factor influencing entrepreneurial motivation. Rajabi et al. (2018) explores the relationship between entrepreneurial motivation and business development from the sales side, showing that entrepreneurial motivation has a positive effect on business development.

The results of the study indicate that entrepreneurial motivation has a significant direct effect on the development and operations of the company. However, most of the studies investigating entrepreneurial motivation have not consistently analyzed the business and environmental impacts surrounding entrepreneurial perceptions. Therefore, entrepreneurial motivation is studied in relation to marketing performance as comprehensively as possible, entrepreneurial motivation as the inner driving force of entrepreneurs (BarbaSánchez and Atienza-Sahuquillo, 2017). Drawing on the above, that entrepreneurial motivation is an encouragement or enthusiasm to become an entrepreneur in any situation, refering to how to react to trends and competitive demands, market opportunities by taking the initiative and leading in the market. Dimensions of entrepreneurial motivation (Aima et al., 2020; Ismail et al., 2016) are opportunity motivation and survival motivation. The dimensions of opportunity motivation include: realizing dreams, proving yourself, and market opportunities. Dimensions of survival motivation include: getting rich, not satisfied with the status quo, and difficulty working.

Previous research that discuss the relationship of entrepreneurial motivation to performance both in developed and developing countries have been widely carried out (Cachon et al., 2013; Robichaud, 2001; Halim, Mat, \& Aziz, 2011). However, there has never been any research on the relationship between entrepreneurial motivation on performance where measurement is not seen from the financial side, but in terms of marketing performance in the perspective of business managers.

Research develops various measures of business performance (Hadji, Monales and Dickson, 2000), using increased sales, employee satisfaction, profitability, and improvement market growth. Marketing performance is multidimensional (Clark, 2000; Clark and Ambler, 2001; Morgan, et al., 2002; Vorhies and Morgan 2003), because the concept of marketing performance reflects multidimensional character, it is necessary to have an integrated model to measure marketing performance. Marketing must have greater accountability and credibility (Luo and Donthu, 2006; O'Sullivan and Abela, 2007; Stewart 2008). The most important tools for measuring marketing performance, Clark (1999) are market share, customer satisfaction, customer loyalty/retention, brand equity, and innovation. An urgent need for further research on marketing performance is to apply a model using empirical data obtained from the perspective of business actors. In 2000, Clark developed a marketing performance measurement from a managerial perspective consisting of efficiency, adaptation, effectiveness, and satisfaction. Kirca et.al (2005), using measurements of customer satisfaction, employee satisfaction, sales growth, and profitability. However, providing entrepreneurial results does not affect marketing performance. Different measurements of marketing performance (Nuryakin et al, 2016), measured by sales growth, profitability and market share growth. Therefore, recommending a hypothesis: entrepreneurial motivation affects marketing performance. The model is illustrated in the following:

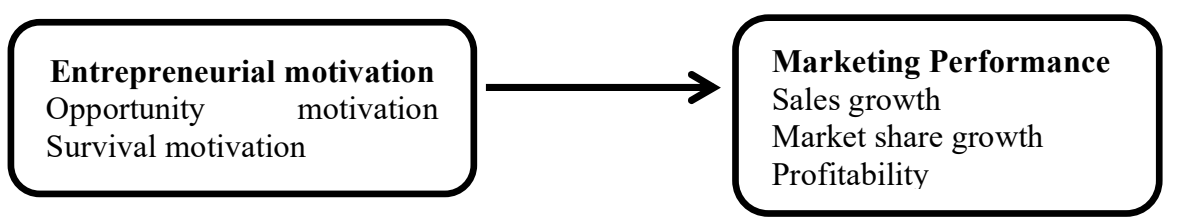

Figure 1. Research Concept Framework

\section{Method}

The data have been collected using questionnaire. T-test is used to investigate, the validity of response then statistical analysis (i.e. regression andcorrelation) study the relationship between entrepreneurial motivation and marketing performance for hypotheses testing on the other hand. Descriptive analysis (i.e. mean, standard deviation) is employed to investigate the importance of entrepreneurial motivation and marketing performance. The questionnaire of the study developed based on indicators of Aima et al., (2020), a n d Nuryakin, (2016) of marketing performance. 5-point Likert scale is used in developing the questionnaire to investigate entrepreneurial motivation and marketing performance factors.

The population of this study consists of food and beverage SME entrepreneurs who have been operating for at least 3 years. Through Krejcie and Morgan sampling formula and simple random sampling method in accordance with the size, 169 entrepreneurs have been selected as the sample.

Regression analysis used to assess the ability of the model to explain the linkage entrepreneurial motivation 
and marketing performance, the dependent variable. As we test the model using regression, the appropriate comparative diagnostic is the Adjusted $\mathrm{R}^{2}$.

\section{Result and Discussion}

Based on statistical results obtained validity and reliability:

Table 1 . Validity and Reliability Test

\begin{tabular}{|c|c|c|c|c|c|c|}
\hline Statement & $\begin{array}{l}\text { Correlation } \\
\text { coefficient }\end{array}$ & $\mathbf{r}$ atse & Sig & Description & $\begin{array}{l}\text { Cronbach } \\
\text { Alpha }\end{array}$ & Description \\
\hline Giving product safety guarantee & 0,667 & 0,148 & 0,000 & Valid & & \\
\hline $\begin{array}{l}\text { Ensuring products are processed } \\
\text { hy gienically }\end{array}$ & 0,647 & 0,148 & 0,000 & Valid & & \\
\hline Change life with hard work & 0,717 & 0,148 & 0,000 & Vakd & & \\
\hline My fate is d etermined by my efforts & 0,635 & 0,148 & 0,000 & Valid & & \\
\hline $\begin{array}{l}\text { Use technology assistance and exp erts } \\
\text { to achieve goals }\end{array}$ & 0,645 & 0,148 & 0,000 & Valid & & \\
\hline $\begin{array}{l}\text { Use social media for advertising } \\
\text { messages }\end{array}$ & 0,578 & 0,148 & 0,000 & Valid & & \\
\hline $\begin{array}{c}\text { Survival } \\
\end{array}$ & & & & & & \\
\hline Knowing market demand & 0,670 & 0,148 & 0,000 & Valid & & \\
\hline Meet the needs of consumers & 0,669 & 0,148 & 0,000 & Valid & & \\
\hline I believ e that I am capable & 0,621 & 0,148 & 0,000 & Valid & & \\
\hline I am competent & 0,608 & 0,148 & 0,000 & Valid & & \\
\hline $\begin{array}{l}\text { The products produced have } \\
\text { special characteristics that cannot be } \\
\text { imitated bycompetitors }\end{array}$ & 0,401 & 0,148 & 0,000 & Valid & & \\
\hline $\begin{array}{l}\text { There is an opportunity for } \\
\text { create new products }\end{array}$ & 0,617 & 0,148 & 0,000 & Valid & & \\
\hline Opportunity & & & & & & \\
\hline EntrepreneurialMotivation & & & & & 0,846 & Reliable \\
\hline Sales increase every y year & 0,688 & 0,148 & 0,000 & Valid & & \\
\hline Marketing area is expanding & 0,649 & 0,148 & 0,000 & Valid & & \\
\hline $\begin{array}{c}\text { Sales Growth } \\
\end{array}$ & & & & & & \\
\hline $\begin{array}{l}\text { The number of } v \text { isitors increases } \\
\text { every week }\end{array}$ & 0,589 & 0,148 & 0,000 & Valid & & \\
\hline New customer increase & 0,673 & 0,148 & 0,000 & Valid & & \\
\hline Customer Growth & & & & & & \\
\hline $\begin{array}{l}\text { Achiev ement of corporate profits that } \\
\text { continues to increase }\end{array}$ & 0,635 & 0,148 & 0,000 & Valid & & \\
\hline The resulting profit exceeds target & 0,663 & 0,148 & 0,000 & Valid & & \\
\hline Profitability & & & & & & \\
\hline
\end{tabular}

Based on table 1. the results show that all statements provide a correlation coefficient value $>r$ table, thus all items are declared valid. While the reliable $r$ value $>0.6$, means that the variables of entrepreneurial motivation and marketing performance are reliable.

The results of the causality equation of entrepreneurial motivation on marketing performance are as follows:

Table 2. Regression Result

\begin{tabular}{|l|c|c|c|c|}
\hline \multicolumn{1}{|c|}{ Variable } & regression coefficient & $\mathrm{T}_{\text {count }}$ & Sig. & Desicion \\
\hline Entrepreneurial Motivation & 0,737 & 13,937 & 0,000 & Sig. \\
\hline Constants & 0,809 & & & \\
$\mathrm{R}$ & 0,873 & & \\
$R$ square & 0,762 & & \\
$\mathrm{~F}_{\text {count }}$ & 194,243 & & \\
Sig. F & 0,000 & & \\
$\mathrm{n}$ & 169 & & \\
\hline Dependent Variable $=$ Marketing Performance & & \\
\hline Line equation : $\mathrm{Y}=0,809+0,737 \mathrm{X}+\varepsilon$ & \\
\hline $\mathrm{F}_{\text {table }}=3,91$ & \\
$\mathrm{t}_{\text {table }}=\quad 1,960$ &
\end{tabular}

Table 2. explains that the r-Square value of 0.762 shows a direct influence on entrepreneurial in the $23.8 \%$ model. The strength of the relationship between the two variables is $87.3 \%(\mathrm{R}=0.873)$. The resulting regression model $\left(\mathrm{F}_{\text {count }}>\mathrm{F}_{\text {table }}=194,243>3,91\right)$, it can motivation on marketing performance by $76.2 \%$, so the influence of other variables that are not explained be said as a 'fit' model in explaining the influence of entrepreneurial motivation on marketing performance of food and beverage SMEs. On the basis of the resulting regression model $\mathrm{Y}=0,809+0,737 \mathrm{X}$, revealed that entrepreneurship motivation has a positive effect on marketing performance (0.737), with a t-count value $=13.937$ and a $t_{\text {-table }}$ value $=1.960\left(t_{\text {-count }}>t_{\text {-table }}\right)$ at a significance value of $0.000<0.05$ so it can expressed that Ho is rejected or Ha is accepted.

The results of the study found that, all indicators used to measure entrepreneurial motivation according to the perception of SMEs food and beverage is a business opportunity and survival. This result shows that food and beverage SMEs have entrepreneurial motivation that is formed from opportunities and survives, as previous studies by Aima et al., (2020) and Ismail et al., (2016), Robichaud, (2001). Marketing performance is the latent variable of micro-enterprises (buildings) which is formed from sales growth indicators, customer growth, and profitability 
growth (Nuryakin et al, 2016). Research result shows that SMEs in this study still rely on the spirit, passion and drive to become entrepreneurs.

The results of the analysis show that entrepreneurship motivation has a significant positive effect on the marketing performance of food and beverage SMEs. That is, the more enthusiasm and passionate in taking opportunities and surviving, the business in the food and beverage sector will growth and develop because business actors will work seriously to realize dreams that have implications for improving marketing performance as a business performance.

An entrepreneur is a person who has an entrepreneurial nature and generally has the courage to take risk, especially in dealing with a business or company, depends on one's own ability and willingness (Rajabi, 2018). This opinion shows that entrepreneurship is closely related to the ability which includes the ability to manage the business and competent. These results support the research conducted by Halim (2011), Cachon, et al. (2013), who found that businesses that Those who have high motivation have much better business performance than those who have low motivation. These results are also in line with the results of research conducted by Baum, et.al. (2001) who found that personal aspects consisting of motivation and competence affect business growth. Lee and Tsang (2011) also found that the personal aspect is described by indicators of the need for achievement and achievement personal motivation shows a positive correlation with performance.

\section{Conclusion}

Food and beverage SMEs understand that entrepreneurial motivation is important in generating performance. This can be proven by the indicators used in the measurement entrepreneurial motivation. This means that entrepreneurial motivation to achieve progress and business growth is determined by the spirit and enthusiasm to take opportunities and survive. Excellent marketing performance in the food and beverage SME sector shows that it is determined by sales growth, customer growth, and increased profit growth. Entrepreneurial motivation has a positive and significant effect on marketing performance. This shows that the higher the spirit of managing the business, the better the business performance. Food and beverage SMEs need to foster entrepreneurial motivation within themselves to try their best to develop their own business

\section{References}

Aima, M. H., Wijaya, S. A., Carawangsa, L., and Ying, M. (2020). Effect of global mindset and entrepreneurial motivation to entrepreneurial self-efficacy and implication to entrepreneurial intention. Dinasti Int. J. Digit. Bus. Manag. 1, 302-314. DOI: 10.31933/dijdbm.v1i2.160

Avgerou, C., and Li, B. (2013). Relational and institutional embeddedness of web-enabled entrepreneurial networks: case studies of netrepreneurs in China. Inf. Syst. J. 23, 329-350. DOI: 10.1111/isj.12012

Baisheng Shi and Tao Wang, (2021), Analysis of Entrepreneurial Motivation on Entrepreneurial Psychology in the Context of Transition Economy, Front. Psychology. 12:680296. DOI: 10.3389/fpsyg.2021.680296

Barba-Sánchez, V., and Atienza-Sahuquillo, C. (2017). Entrepreneurial motivation and self-employment: evidence from expectancy theory. Intternational Entrepreneurship Management Journal. 13, 1097-1115. DOI: $10.1007 / \mathrm{s} 11365-017-0441-\mathrm{z}$

Bartha, Z., Gubik, A. S., and Bereczk, A. (2019). The social dimension of the entrepreneurial motivation in the central and eastern european countries. Entrepreneurship Business Economic Review, 7, 9-27. DOI: 10.15678/EBER.2019.070101

Baum, and Locke, (2004), The Relationship of Entrepreneurial Traits, Skill, and Motivation to Subsequent Venture Growth, Journal of Applied Psychology 89(4):587-598 DOI: 10.1037/0021-9010.89.4.587

Baum, Locke, \& Smith (2001), A Multi-Dimensional Model of Venture Growth, The Academy of Management Journal 44(2) , 292-303. DOI: 10.2307/3069456

Cachon, J. C., Codina, J. B., Eccius-Wellmann, C., McGraw, E.,\& Myers, D. A. (2013), Entrepreneurial Motives and Performance: Evidence from North America. Journal ofManagement Policy and Practice, 14(3), 50-77.

Clark, B.H. (1999). Marketing Performance Measures: History and Interrelationships, Journal of Marketing Management. 15, 711-732.

Clark, B.H. (2000). Managerial Perception of Marketing Performance: Efficiency, Adaptability, Effectiveness and Satisfaction, Journal of Strategic Marketing. 8, 1, 3-25.

Clark, B.H. and Ambler, T. (2001). Marketing Performance Measurement: Evolution of Research and Practice, International Journal of Business Performance Management. 3, Winter, 231-244.

Gao, Y. (2010). Measuring marketing performance: a review and a framework, Marketing Review, Vol. 10, No. 1, 25-40. DOI: 10.1362/146934710X488924

Gerry Segal, Dan Borgia and Jerry Schoenfeld (2005), The motivation to become an entrepreneur, International Journal of Entrepreneurial Behaviour \& Research, Vol. 11 No. 1, 42-57

Hadjimonalis, Anthanasios., Keith Dickson (2000), Innovation Strategies of SMEs in Cyprus, A Small Developing Country, International Small Business Journal. 18,4, 62-79 
Halim, M. A. S. A., Mat, A. C., \& Aziz, W. A. W. A. (2011).The Impact of Enterpreunerial Motivation Toward Business Performance among SMEs in Creative Industry. Elixir Marketing Management, 35, 2764-2767

Ismail, I., Husin, N., Rahim, N. A., Kamal, M. H. M., and Mat, R. C. (2016). Entrepreneurial success among single mothers: the role of motivation and passion. Procedia Economic Financial. 37, 121-128. DOI: $10.1016 / \mathrm{S} 2212-5671(16) 30102-2$

Kirca, A. H., Jayachandran, S., \& Bearden, W. O. (2005). Market orientation: a meta-analytic review and assessment of its antecedents and impact on performance. Journal of Marketing, 69(2), 24-41

Lee, D.Y. dan Tsang. 2001. The Effects of Entrepreneurial, Personality, Background and Net Work Activities on Venture Growth. Journal Of Management Studies. Vol. 38(4) 583-602.

Luo, X. and Donthu, N. (2006), Marketing's Credibility: A Longitudinal Investigation of Marketing Communication Productivity and Shareholder Value, Journal of Marketing. 70, 4, 70-91.

Morgan, N.A., Clark, B.H., and Gooner, R. (2002). Marketing Productivity, Marketing Audits, and Systems for Marketing Performance Assessment: Integrating Multiple Perspectives, Journal of Business Research. 55, 5 , $363-375$.

Nuryakin, N. And Retnawati, B. B., (2016), Using Technological Relational Capabilities to Investige Marketing Performance in International Wooden Market, Journal Information, Vol. 19 (7A), p. 2555-2563

O'Sullivan, D. and Abela, A.V. (2007). Marketing Performance Measurement Ability and Firm Performance, Journal of Marketing. 71, 2, 79-93.

Rajabi, R., Brashear-Alejandro, T., and Chelariu, C. (2018). Entrepreneurial motivation as a key salesperson competence: trait antecedents and performance consequences. Journal of Business. Ind8ustrial Marketing 33, 405-416. DOI: 10.1108/JBIM-12-2016-0278

Robichaud, Y., McGraw, E., \& Roger, A. (2001). Toward the Development of A Measuring Instrument for Entrepreneurial Motivation. Journal of Developmental Entrepreneurship, 6(2), 189-201

Stewart, D.W. (2009). Marketing Accountability: Linking Marketing Actions to Financial Results, Journal of Business Research. 62, 636-643.

Su, X., Liu, S., Zhang, S., and Liu, L. (2020). To Be Happy: a Case Study of Entrepreneurial Motivation and Entrepreneurial Process from the Perspective of Positive Psychology. Sustainability 12, 1-27. DOI: $10.3390 /$ su 12020584

Vorhies, D.W. and Morgan, N.A. (2003). A Configuration Theory Assessment of Marketing Organization Fit with Business Strategy and Its Relationship with Marketing Performance, Journal of Marketing. 67, 100-115. 